\title{
The Contribution of Reformist Movement to the Development of Islamic Education in Malaya after Independence
}

Nor Adina Abdul Kadir, Mohd Farhan Abd Rahman, Hamidah Jalani, Muhd Imran Abd Razak, Ahmad Firdaus Mohd Noor, Nurul Kamalia Yusuf

To Link this Article: http://dx.doi.org/10.6007/IJARBSS/v11-i5/9928

DOI:10.6007/IJARBSS/v11-i5/9928

Received: 01 April 2021, Revised: 26 April 2021, Accepted: 02 May 2021

Published Online: 20 May 2021

In-Text Citation: (Kadir et al., 2021)

To Cite this Article: Kadir, N. A. A., Rahman, M. F. A., Jalani, H., Razak, M. I. A., Noor, A. F. M., \& Yusuf, N. K. (2021). The Contribution of Reformist Movement to the Development of Islamic Education in Malaya after Independence. International Journal of Academic Research in Business and Social Sciences, 11(5), 346-355.

Copyright: @ 2021 The Author(s)

Published by Human Resource Management Academic Research Society (www.hrmars.com)

This article is published under the Creative Commons Attribution (CC BY 4.0) license. Anyone may reproduce, distribute, translate and create derivative works of this article (for both commercial and non-commercial purposes), subject to full attribution to the original publication and authors. The full terms of this license may be seen at: http://creativecommons.org/licences/by/4.0/legalcode

Vol. 11, No. 5, 2021, Pg. 346 - 355

Full Terms \& Conditions of access and use can be found at http://hrmars.com/index.php/pages/detail/publication-ethics 


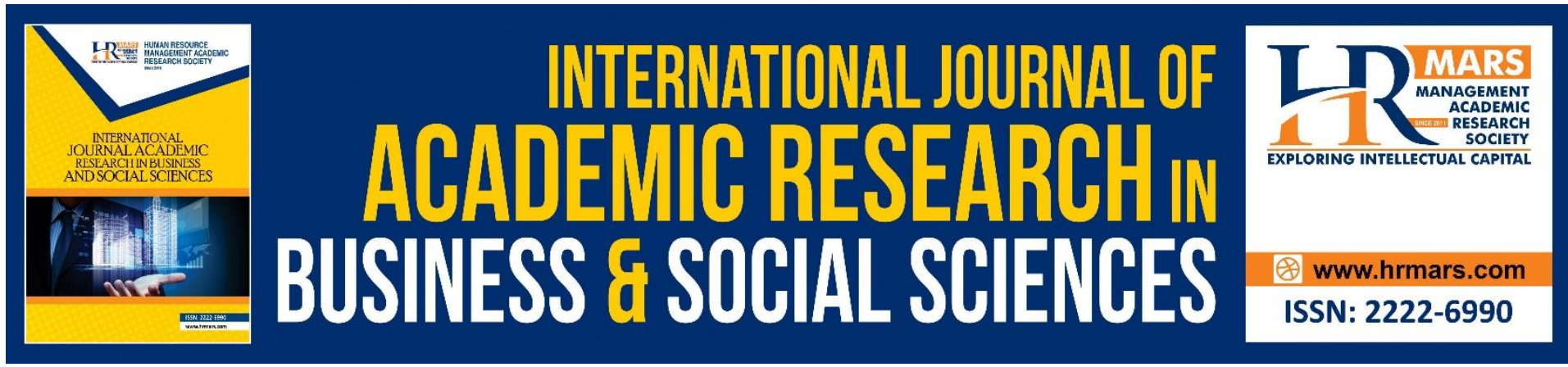

\title{
The Contribution of Reformist Movement to the Development of Islamic Education in Malaya after Independence
}

\author{
Nor Adina Abdul Kadir ${ }^{1}$, Mohd Farhan Abd Rahman², Hamidah \\ Jalani ${ }^{1}$, Muhd Imran Abd Razak (Ph.D) ${ }^{2}$, Ahmad Firdaus Mohd \\ Noor (Ph.D)2 $)^{2}$ Nurul Kamalia Yusuf (Ph.D) ${ }^{3}$ \\ ${ }^{1}$ Academy of Contemporary Islamic Studies (ACIS), Universiti Teknologi MARA, Melaka \\ Branch, Alor Gajah Campus, Alor Gajah, 78000 Melaka, Malaysia, ${ }^{2}$ Academy of \\ Contemporary Islamic Studies (ACIS), Universiti Teknologi Mara, Perak Branch, Seri Iskandar \\ Campus, Seri Iskandar, 32610 Perak, Malaysia, ${ }^{3}$ Academy of Language Studies, Universiti \\ Teknologi MARA, Perak Branch, Seri Iskandar Campus, Seri Iskandar, 32610 Perak, Malaysia
}

\begin{abstract}
The scholars, intellectuals or the intelligentsia involved in the Islah efforts in Malaya were known as Kaum Muda or the reformist faction. The emergence of Islah movement in Malaya in the early $20^{\text {th }}$ century challenged the status quo and religious institutions as well as the existing government. Some Muslims were suspicious of the reformists' presence in the society. This is due to their controversial principles, especially in fiqh where the majority of Muslims in both Malaya and the Malay Archipelago were practitioners of the Shafi'i Mazhab. The development of this movement had provoked disputes between the two schools of thought of Kaum Tua and Kaum Muda. Such a controversial environment had rendered their contributions being unable to receive due recognition. Hence, this article will discuss some of the roles of the reformist movement by the reformist faction, by re-examining their contributions, particularly with regard to long-term contribution to the development of the community in Malaya.
\end{abstract}

Keywords: Islah Movement, Kaum Tua, Kaum Muda, Islah in Malaysia

\section{Introduction}

In Islamic history, the concept of Islah is essential in the development of Muslim civilisations. Islah is an effort to return a situation to a state that is correct, accurate and appropriate. Islah gives a clear meaning by referring to the process of reparation and restoration of something that is fasad (damaged). History has recorded that a doctrine can last for a long time if it meets the four main conditions. Firstly, its validity of logic and argumentation; secondly, it attracts people; thirdly, it is something that can be applied to cases that confront it; and fourthly, it has the mechanism for a reform process of renewing old ideas without leaving the most important traditions (Faruqi, 2000). These four conditions are indeed possessed by the major Islamic sects that enable them to remain to this day (Minhaji, 2005). The ulama of Malaya 
who were oriented towards Islah referred to those who were influenced by the ideas of Sheikh Muhammad 'Abduh, spearheaded by Sheikh Tahir Jalaluddin, Syed Sheikh al-Hadi, Haji Taha Abbas and many others in the early $20^{\text {th }}$ century. When exactly did the movement appear is quite challenging to be determined. Generally, its first appearance was detected in the early $20^{\text {th }}$ century. The year 1906 was considered an important date in the Islah movement with the publication of al-Imam magazine in Singapore. Islah Movement in Malaya emerged as an internal response to the phenomenon of stagnation of the Muslims in the country. It took place in an environment of Western colonial invasion of Malaya, with worsening of economic performance of the Malays as compared to other immigrants, as well as the influx of a large number of immigrants to the country. These phenomena clearly highlighted the severe crisis of the Muslims in Malaya at that time. Hence, the pioneers of Islah in Malaya believed that improvement efforts and purification (Islah) had become important in order to rectify the state of the people. In carrying out the Islah effort, they emphasised on the restoration of pure Islamic teachings in the society and the change of attitude in order to escape the shackles of economic decline and intellectual stagnation (Zakariya, 2019).

The reformists of Kaum Muda pioneered by Sheikh Tahir and Syed Sheikh al-Hadi in Malaya were influenced by the Muhammad 'Abduh's perspective. According to Roff (1962, 213):

It (al-Imam) was deeply and directly influenced by al-Manar Salafiyya movement in Cairo (on whose journal of that name it was modeled, and whose contents it often reproduced), and its links with Middle East are further reflected in its promotion of the first modern-style Islamic school.

This shows that the Al-Imam magazine was among the pieces of evidence that showed the influence of 'Abduh over the Islah group in Malaya. The emergence of the Islah movement brought by Muhammad 'Abduh and Sayyid Rashid Rida - posed a great challenge to the existing religious institutions and practices because these reformists hade the ambition to cleanse Islam from what they saw as the pollution of superstition, heresy and blind taqlid (Jamil, 1997). These two Islah's pioneers were the proponents who brought the ideas of Islamic reform based on Western modernisation without disregarding the core of Islam (Jasmi, 2007).

\section{The Ulama and Kaum Muda in the Development of Education}

Prior to the advent of Islam, the Jahiliya Arabs were known to be vicious, ignorant and uncivilised. The arrival of Islam introduced the Arabs to the concepts of knowledge, teaching, writing, reading and pen (El-Muhammady, 1991). Islam arrived intending to change people's view of life and take them in a better direction. This is because the education system is closely related to knowledge and there is no escape from reading, investigation and research. The first revelation revealed to the Prophet Muhammad about 1400 years ago, surah al-Alaq, clearly shows that reading and knowledge are important. Knowledge in Islam aims to bring people to the truth in life, both in the world and hereafter. The absolute source of truth is God, the One who created that knowledge and truth (Faruqi, 2000).

In the context of Malaysian history, it is not too much to say that the development of a positive intellectual mindset that has been able to enlighten and generate more positive modernisation stems from external influences (Rahim, 2001). The effectiveness of these 
external influences depends on the openness and willingness of the locals to adopt and adapt them to the local characteristics. In the Malaysian context, external influence can be traced to the religion of Islam itself. It can be seen from the beginning of the process of Islamisation of the Malay world when the conversion of a king was one of the major factors behind the speed of Islamisation in the Archipelago (Al-Attas, 1969). Much has been said about the conversion of a king to Islam and his role as the main reason behind the process of Islamisation and the speed of its propagation (Abdullah, 2000).

In addition to the rapid development of Islamic educational institutions, which fueled the intellectual growth of the Malay community, the preservation of Islamic influence had to face the challenge of colonialism, which finally led to the development of the Islamic revival movement that had a profound effect on the Malay community (Musa, 2001). This reciprocal process would continue in Malaysia due to the Malay community's acceptance of the concept of Ummah, which has been developed by Islamic teachings (Rahim, 2002). The concept of Ummah is an important foundation that promotes the bonds of brotherhood that often exists between scholars, preachers and merchants of Islam (Abdullah, 2000).

At the beginning of the $20^{\text {th }}$ century, a new movement was initiated by those educated in Islamic education, especially those who received their education in Egypt. This movement was known as the Islah movement (reformation), referring to a religious movement to eradicate the elements of shirk, superstitions and heresies among the Muslim community and restore the teachings brought by Prophet Muhammad based on the Quran and Hadith (Yahaya, 1998). The propagation of this thought began when the newspaper al-Imam was published in 1906 and its existence was influenced by the al-Manar newspaper published in Egypt. Its publication seemed to attest to spread of polemic of thought - which had taken place in Egypt previous - in Malaya, with the existence of Kaum Tua and Kaum Muda. Kaum Muda wanted reform while Kaum Tua were more comfortable with traditional Islamic practices in Malaya.

Based on our observation of the Islamic intellectualism in Malaya, it is not surprising that the trigger brought about by Kaum Muda, under the leadership of Sheikh Tahir Jalaluddin (1869-1956) and Syed Sheikh al-Hadi (1867-1934), resulted in sociocultural, political and economic changes of the Malays historical development (Ismail, 2005). The period between the 1900s and the 1940s saw a striking contrast between the two main factions in providing the Malay with answers to how Islam responds to the modernisation brought by the British (Bakar, 1994).

The though development among the Middle East reformers had also influenced the young people in Malaya in general and in Malaysia in particular. Literature was among the vessel of Malay thought, which also played a significant role in changing the attitudes among young people, and there was resistance from the older generation who wanted to maintain the old thought values (Ismail, 2005).

For the Kaum Tua consisting of traditional ulama and the Malay aristocrats, in order to maintain the well-being of the Malay and Muslim community itself, we must consider the fact that modernisation can be a dangerous process. Thus there was a need to preserve the conventional way of life. In other words, Kaum Tua preferred that the Muslims return to the orthodox way of life and resist any forms of modernisation (Bakar, 1994). Conversely, the Kaum Muda had been attuned to progressive thinking since the $20^{\text {th }}$ century and had greatly impacted the intellectual stream in Malaysia (Ismail, 2005). Understanding the elements of colonialisation and globalisation had shaped their thoughts when addressing the challenges faced by the Muslim Malays. Their ideas had been disseminated through the intellectual 
media, i.e. the 'print nationalism', and became the catalyst of a number of movements, NGOs and prominent Malay thinkers. Subsequently, these ideas had influenced modern political thought and given rise to the awareness of the progressive process of Islamisation for cultural, social and political institutions (Ismail, 2005).

Malay students studying in the Middle East in the late $19^{\text {th }}$ and early $20^{\text {th }}$ centuries were the ones with active initiative. This can be seen from their dynamic involvement in union activities and publishing their own newspapers and forming printing companies to spread ideas that brought about awareness to the Malay community effectively. The roles played by Al-Azhar University graduates and those who studied in Makkah were crucial in raising Malay awareness before World War II. In addition to serving as a center for Malay education, it had also emerged as a center for the development of Malay intellectualism.

The authors can state several factors that led to the intellectual movement of the Malay student at that time. First, it was due to the existence of printing centres that printed books in Arabic and Malay for the use of the Malay community in the Hijaz and throughout the Malay Archipelago. The presence of printing centres played an important role as the printed books brought knowledge to the people. Second, exposure to the scholarly environment had also affected the development of the minds of Malay students who were in Makkah (Othman, 2006).

This can be seen from their reaction to issues that appeared in Malay newspapers and magazines of the time such as Tunas Melayu, Neracha, Idaran Zaman, Bahtera and Malaya. The students who studied there not only regular readers and subscribers to the newspapers but also contributed valuable ideas and insights to the publications. The existence of newspapers and magazines highlighting current issues in the Malay world affected the students' thought development.

Therefore, it is clear that the influence that came from the Middle East also brought about social change in society when those educated in the region - and became known as the ulama - pioneered the development of education for the Malay people. In addition to the Middle Eastern education that shaped the intellectual culture, it was also a source of early Malay political consciousness. The evidence can be seen from the early influence of nationalism of the Malay people, which was Pan-Islamism that experienced rapid growth in the Middle East between the end of the $19^{\text {th }}$ century and early $20^{\text {th }}$ century (Saat, 2007).

Consequently, several Islamic movements brought the idea of Islamic consciousness to their homeland. One of them was an alumnus of Madrasah Idrisiah and a student of Sheikh Abdullah Fahim (1870-1961), Abu Bakr al-Baqir (1907-1974), who founded the Hisbul Muslimin on March 14, 1948 (Kadir et al., 2020). However, the organisation was seen as a threat, and the colonisers banned it in August 1948. It did not have the chance to establish itself in Malaya since Hizbul Muslimin was accused of extremism. The British did not want to risk the chance that it would gather the people's support and eventually achieve independence to form an Islamic nation.

\section{The contributions of the Islamic Movement in the Development of Islamic Education}

The massive reform of the religious education system was parallel with the rise of the Islamic movement in the early 1970s. In Malaysia, the emergence of ABIM, an organisation that continued the struggle for Islam among students and intellectuals through PKPIM and alRahmaniah had given a new dimension to religious education. The tarbiyyah approach, which combined the secular and Islamic knowledge, had given place to religious education in various institutions. ABIM introduced this idea through its first private school, Yayasan Anda, in 1971. 
The private school - which was established to reduce the number of Muslims students who were unable to enter local universities - was also infused with an Islamic hierarchical approach similar to Ikhwan al-Muslimin introduced through activities such as usrah, tamrin dan qiamullail. The purpose and role of Yayasan Anda attracted many Western researchers such as Nagata (1984), who described it as an educational institution that made religion the main basis in navigating the mainstream of the national education system. Nagata (1984) also agreed with the Yayasan Anda's orientation that produced sustainable students in terms of modern (secular) and religious education even though the foundation of educational institutions did not start with traditional patterns as practiced by people-funded religious schools and pondok.

$A B I M$ was also active in defending and modernising the pondok institution and people funded-schools as implemented at Maahad al-Ummah in Chemor, Perak. ABIM further increased the systematic tarbiyyah efforts from the childhood level to through the tertiary institution level. Several educational institutions such as Taman Asuhan Kanak-Kanak (TASKI) in 1979 and later followed by Sekolah Rendah Islam (SRI) or Islamic Primary School; Sekolah Menengah Islam (SMI) or Islamic Secondary School; Insititut Pengajian IImu-ilmu Islam (IPII) or the Islamic Sciences Institute; and Institut Perguruan (IPA) or the ABIM Teaching Institution were opened to members and the general public. It is no exaggeration to say that ABIM was the pioneer of modern educational systems and institutions from among the Islamic movement. The establishment of these institutions was a manifestation of its desire to see an alternative Islamic-based education system flourish in society. The culture of knowledge or intellect that had been considered the pulse of the Islamic revival by ABIM was clearly trying to be introduced to the community, primarily through its higher education institution, IPII. This institution, which was established in 1991, played an essential role in implementing the idea of 'Islamisation of Knowledge'. This idea has been said to be implemented by breathing the Islamic spirit and perspective in all areas of the subjects involved. For example, in addition to offering Islamic-based courses such as Quran Study, Hadith and Arabic, IPII also offered other courses such as Comparative Law, Islamic Social Science and Islamic Political Thought which were a blend of secular and Islamic knowledge. The level of scholarship at IPII was further enhanced by the existence of twinning programs with local and foreign universities (Nasir, 1999).

Besides, ABIM had been indirectly involved in the process of Islamisation of national education. Members of the ABIM movement developed a national education policy, and it dominated certain educational institutions in Malaysia. ABIM's involvement expanded in the implementation of the National Education Policy launched in 1987. This had produced several ABIM scholars such as Idriz Jauzy, Muhammad Nur Manuty and Wan Mohd Nor in providing views on the Islamisation of national education policy. Their thoughts were in line with those of Anwar Ibrahim, who believed that the process of Islamisation will be successfully implemented if a new education system can be successfully formed based on principles, methods, structures and content taken from Islamic teachings (Nasir, 2010).

$A B I M$ 's efforts to channel its thinking and approach through government educational institutions' mechanism met with setbacks when its former president Anwar Ibrahim was sacked as Deputy Prime Minister in 1998. International Islamic University Malaysia (IIUM), formerly known as ABIM Islamic University, was lost to the Islamic movement. However, this did not stop ABIM from fighting for its educational message with other government bodies and NGOs in the country. Many ABIM activists were active in contributing their ideas in educational institutions, especially the Parti Pakatan, which managed to take control of the 
state of Selangor in 2008. Various reforms were made to uphold Islam. One of the pieces of evidence was when Selangor Darul Ehsan Islamic College (KISDAR) was upgraded to the Selangor Islamic University College (KUIS), which has opened up ample space for the Islamic movement to play a role in institutions of higher learning that were previously closed to the opposition. Among the involvement of ABIM activism in KUIS was in March 2009, with a regional seminar commemorating the 100th Anniversary of the National Hero, Mr. Mohamad Natsir, an Indonesian $d a^{\prime} w a h$ and education figure who had greatly influenced ABIM and the Islamic movement in Malaysia. The seminar organised by Wadah Pencerdasan Umat Malaysia (WADAH) in collaboration with KUIS and officiated by Anwar Ibrahim is believed to be the catalyst for the Islamic movement to spread the idea of education among scholars in higher education institutions in the country (Nasir, 2010).

The emphasis placed by ABIM on tarbiyyah and education was emulated by Jamaah Islah Malaysia (JIM), a social missionary movement purportedly from Islamic Representative Council (IRC), also known as Majlis Syura Muslimin (Anwar, 1990). IRC appeared on the public stage with the image of tarbiyyah and Islah through programs conducted professionally and systematically within JIM. This had been in line with the background of this movement which had been supported by professional and corporate figures (Anwar, 1990). Like ABIM, JIM became increasingly known to the community through various programs such as the Institut al-Quran, Da'wah Training Institute IWC-JIM and the development of al-Amin primary and secondary schools as well as the Jaiputra College in Kota Bharu Kelantan.

JIM managed to attract the attention of the community with al-Amin schools. The schools, as an institution, laid as its foundation the principle of monotheism for building and producing characters who are noble, believing, faithful, moral and sustainable in shaping themselves, society and the country as outlined in the Quran and the Sunnah. The general educational goal is to form a generation of muttaqin who are able to appreciate and fight for Islam as a whole. Thus, Islamic education and the Arabic language have been given priority. The curriculum used has been taken from several religious schools in Kelantan and Terengganu, which are parallel with the Ministry of Education Malaysia curriculum. Educational institutions under JIM not only emphasise spirituality but also take into account academic aspects, life skills and modern technology (Yusop, 1993).

JIM continued to expand its educational institutions by creating a network of Islamic schools throughout Malaysia consisting of 30 schools at the primary and secondary levels. Also, JIM worked with its members at the tertiary level by establishing an organisation called Kelab Rakan Siswa Islah Malaysia (KARISMA) on $2^{\text {nd }}$ May 1999. KARISMA was established to implement Islah and $d a^{\prime} w a h$ efforts for students. JIM's tendency to use this informal approach was due to the movement's approach to being more open in the community without the need for a clear container bearing the name of the organisation itself. It also had more inclination towards the method of reform which refers to formal educational activities and a way that was thought to be more practical and responsive to the needs of the society. Thus, JIM has been quite forward in offering social treatment institutions such as Raudhatul Sakinah established in 1998. Raudhatul Sakinah has been serving as a centre of protection and guidance to adolescents who have been victims of social ills. This effort has helped teenagers increase their confidence and ability to be valuable individuals to religion and society.

Overall, the programs and institutions run by JIM or its members have not been not much different from what have been implemented by ABIM. Although JIM could not match ABIM's popularity, especially among the local community, it managed to increase the al-Amin 
school network's speed in urban areas. Its professional image has succeeded in attracting the highly educated to send their children to study at the institution. The presence of JIM in the development of education systems and institutions further adds to the rising tide of a combination of integrated concepts between scholars and intellectuals in the current education system.

\section{Conclusion}

Based on the points discussed, it is undeniable that the Islamic movement had contributed significantly to developing the country's educational institutions. Several Islamic movements dominated the currents of educational revival that had been exposed to modern developments in the world of education. This can be seen from their efforts to develop educational institutions in line with the progress of the modern education and the open attitude of the movement bodies to incorporate part of the mainstream education of the country. Their tendency to establish Islam as the basis in education was a factor that separated them from the current education curriculum that was still secular. Islamic movements such as ABIM and JIM had successfully introduced an alternative Islamic education system that was translated either in the form of their private institutions or the making of policies and their implementation in the existing system. This proves that political differences or approaches in implementing Islamic teachings were not an obstacle for them to participate in jointly advancing education development in this country. Some positive aspects of the educational orientation of the Islamic movement, whether it is Sufism, social welfare and politics might be developed in the current education system by conducting comprehensive and objective scientific research conducted by scholars.

The controversial Islah movement's stance especially their rejection of taqlid attitude towards Shafi'i mazhab has marginalized them from the mainstream Muslim community. Moreover, their bravery in criticizing the feudal leaders including the sultans, rulers, ulama caused their standpoint to be viewed as a major threat to status quo. Despite the Islah community had a small number of followers, they made significant changes in the society, especially in pioneering nationalism awareness and improving the religious education system by putting forward the integration model in the middle of Pondok educational system and the mainstream (secular) education. In that way, graduates from the madrasah have a balance and holistic exposure to religious issues and the contemporary knowledge that prepare them in dealing with the present-day challenges faced by Muslims. The Islah group operating outside the system of religious lodges and administrations are faced with the challenging tasks as the Islamic Religious Council is controlled by the rulers and traditional scholars. In fact, their contribution to the Malay community is highly significant despite the arduous challenges. Albeit their weaknesses and drawbacks, they still make a big contribution in shaping the development of religious, educational, and political spells in the country.

\section{Corresponding Author}

Mohd Farhan Abd Rahman

Academy of Contemporary Islamic Studies (ACIS), Universiti Teknologi MARA, Perak Branch, Seri Iskandar Campus, 32610 Seri Iskandar, Perak, Malaysia.

Email: farhan84@uitm.edu.my. 


\section{References}

Abdullah, A. (2000). Kerajaan Melayu: Sendi Islam dalam Pemerintahan Tradisi. In Osman, M.T. \& Deraman, A.A. (Eds.). Tamaddun Islam di Malaysia. Kuala Lumpur: Dewan Bahasa dan Pustaka.

Al-Attas, S. M. N. (1969). Preliminary Statement on a General Theory of the Islamisation of the Malay-Indonesian Archipelago. Kuala Lumpur: Dewan bahasa dan Pustaka.

Anwar, Z. (1990). Kebangkitan Islam di Kalangan Pelajar. Kuala Lumpur: Pelanduk Publicatons.

Bakar, I. A. (1994). Islamic Modernism in Malaya: The Life and Thought of Sayid Syekh al-Hadi, 1867-1934. Kuala Lumpur: Penerbit Universiti Malaya.

El-Muhammady, A.H. (1991). Pendidikan Islam: Falsafah, Disiplin dan Peranan Pendidik. Petaling Jaya: Dewan Pustaka Islam.

Faruqi, I. R. (2000). Tauhid: Kesannya Terhadap Pemikiran dan Kehidupan. Kuala Lumpur: Unit Terjemahan Modal Perangsang Sdn. Bhd.

Ismail, H. (2005). Kaum Muda dan Pemikiran Progresif di Malaysia. In Hamdani, H. (Ed.). Islam di Malaysia dan Sastera Nusantara. Kuala Lumpur: Gapeniaga Sdn. Bhd.

Jamil, F. (1997). Islam Zaman Moden: Cabaran dan Konflik. Batu Caves: Thinker's Library.

Jasmi, K. A. (2007). Pembaharuan dalam Dunia Islam. Skudai: Universiti Teknologi Malaysia.

Kadir, N. A. A., Rahman, M. F. A., \& Ayub, M. S. (2020). The Relationship between the Ulama and Malay Intellectuals in the Development of Islamic Education in Perak, 1922-1999. International Journal of Academic Research in Business and Social Science, 10(4), 495508.

Minhaji, A. (2005). Otoritas, Kontinyuitas dan Perubahan dalam Sejarah Pemikiran Ushul alFiqh. In Yusdani, A.M. (Ed.). Ijtihad dan Legislasi Muslim Kontemporer. Yogyakarta: UII Press.

Musa, H. (2001). Merekonstruksi Tamadun Melayu Islam: Ke Arah Pembinaan Sebuah Tamadun Dunia Alaf Ketiga. Kuala Lumpur: Dewan Bahasa dan Pustaka.

Nagata, J. (1984). The Reflowering of Malaysian Islam: Modern Religious Radicals and Their Roots. Vancouver: University of British Columbia Press.

Nasir, B. M. (1999). Metod Dakwah Gerakan Islam Tanah Air: Sorotan terhadap PAS, ABIM dan JIM. Proceeding Seminar Kebangsaan Dakwah dan Gerakan Islam Alaf Baru. Jabatan Pengajian Dakwah dan Kepimpinan, Fakulti Pengajian Islam, Universiti Kebangsaan Malaysia, 10 July 1999.

Nasir, B. M. (2010). Pendidikan dalam Gerakan Islam di Malaysia: Satu Tinjauan. Journal of Islamic and Arabic Education, 2(1), 1-12.

Othman, M. R. (2006). Islam dan Masyarakat Melayu: Peranan dan Pengaruh Timur Tengah. Kuala Lumpur: Penerbit Universiti Malaya.

Rahim, R. A. A. (2001). Al-Quran dan Pemodenan di Alam Melayu : Satu Analisa. Proceeding Seminar Warisan Al-Quran Peringkat Kebangsaan 2001. Pusat Ilmu Kemanusiaan, Universiti Sains Malaysia and Yayasan Dakwah Islamiah Malaysia (YADIM), 24-25 October 2001.

Rahim, R. A. A. (2002). Dakwah dan Jalinan Intelektual di Rantau Alam Melayu-Indonesia: Satu Analisa Sejarah. Proceeding Seminar Antarabangsa Pengajian Dakwah IndonesiaMalaysia. Universitas Muhammadiyah Sumatera Utara and Fakulti Pengajian Islam, UKM, 18 May 2002. 
Roff, W. R. (1962). Kaum Tua and Kaum Muda: Innovation and Reaction amongst Malays, 1900-1940. In Tregonning, K.G. (Ed.). Paper on Malayan History. Singapore: Journal of Southeast Asian History.

Saat, I. (2007), Sejarah Politik Melayu Pelbagai Aliran. Shah Alam: Karisma Publications Sdn. Bhd.

Yahaya, M. (1998). Abu Jabir Abdullah bin Ahmad al-Ghadamisi: Tokoh Ulama Islah di Tanah Melayu. Proceeding Kongres Sejarah Malaysia Kedua, v. 2, 435-447.

Yusop, Z. A. (1993). Jamaah Islah Malaysia (JIM): Sejarah Penubuhan dan Sumbangannya Kepada Dakwah Islamiyyah di Malaysia. Dissertation Universiti Kebangsaan Malaysia.

Zakariya, H. (2019). Sumbangan Gerakan Islah Terhadap Perkembangan Nasionalisme dan Pendidikan Islam di Tanah Melayu. International Journal of Heritage, Art and Multimedia, 2(7), 12-23. 